\title{
COMPARISON PROBLEM SOLVING MATHEMATICS STUDENTS JUNIOR HIGH SCHOOL IN CIMAHI CITY BETWEEN USING MURDER COLLABORATIVE LEARNING MODEL WITH USING A SAINTIFIC APPROACH
}

\author{
Aip Syarif Hasan Efendi \\ IKIP Siliwangi \\ asyarif015@gmail.com
}

Received: June, 2018; Accepted: June, 2018

\begin{abstract}
This research is motivated by the low ability of solving mathematical problems of junior high school students towards mathematics subjects. This study aims to find out whether the problem solving ability of junior high school students using MURDER Collaborative Learning Model is better than the students who use the Scientific Approach. Method in this research is experiment. The population in this study is all students of class VIII SMP Negeri in Kota Cimahi. The sample was taken by random class, from 13 classes obtained two classes, namely VIII-B as experimental class I and class VIII-C as experiment class IIl. The experimental class I used the MURDER Collaborative Learning Model, while the experimental class II used the Scientific Approach. Research data obtained through the instrument in the form of data pretest and postest mathematical problem solving ability. The data were processed by normality test, homogeneity test, and test of difference of two mean using Minitab 17 software. The results showed that the ability of solving mathematical problems of junior high school students using MURDER Collaborative Learning Model is better than students using the Scientific Approach.
\end{abstract}

Keywords: Mathematical problem solving, collaborative learning MURDER, scientific approach

\begin{abstract}
Abstrak
Penelitian ini dilatarbelakangi oleh rendahnya kemampuan pemecahan masalah matematik siswa SMP terhadap mata pelajaran matematika. Penelitian ini bertujuan untuk mengetahui apakah kemampuan pemecahan masalah matematik siswa SMP yang menggunakan Model Pembelajaran Kolaboratif MURDER lebih baik daripada siswa yang menggunakan Pendekatan Saintifik. Metode pada penelitian ini adalah eksperimen. Populasi dalam penelitian ini adalah seluruh siswa kelas VIII SMP Negeri di Kota Cimahi. Sampel diambil secara acak kelas, yaitu dari 13 kelas diperoleh dua kelas, yaitu VIII-B sebagai kelas eksperimen I dan kelas VIII-C sebagai kelas eksperimen IIl. Kelas eksperimen I menggunakan Model Pembelajaran Kolaboratif MURDER, sedangkan kelas eksperimen II menggunakan Pendekatan Saintifik. Data penelitian diperoleh melalui instrumen berupa data pretest dan postest kemampuan pemecahan masalah matematik. Data tersebut diolah melalui uji normalitas, uji homogenitas, dan uji perbedaan dua rata-rata menggunakan software Minitab 17. Hasil penelitian menunjukkan bahwa kemampuan pemecahan masalah matematik siswa SMP yang menggunakan Model Pembelajaran Kolaboratif MURDER lebih baik daripada siswa yang menggunakan Pendekatan Saintifik.
\end{abstract}

Kata Kunci: Pemecahan masalah matematik, pembelajaran kolaboratif MURDER, pendekatan saintifik

How to Cite: Effendi, A. S. H. (2018). Comparison Problem Solving Mathematics Students Junior High School in Cimahi City Between Using Murder Collaborative Learning Model with Using a Scientific Approach. JIML, 1 (2), 51-58. 
52 Effendi, A. S. H. Comparison Problem Solving Mathematics Students Junior High School in Cimahi City Between Using Murder Collaborative Learning Model with Using a Scientific Approach

\section{INTRODUCTION}

In mathematics one of the abilities that must be possessed by students is the ability problem solving. This ability can train students by solving non-routine math problems. So that students can get used to the problems faced. The importance of problem solving is also affirmed in NCTM (Juanda, 2013: 4), "Problem solving is an integral part of mathematical understanding, so it should not be released from mathematics learning". This opinion is confirmed by Sumarmo (Srimulyati, 2014: 3), "Problem solving is the general goal of mathematics learning, even as the heart of mathematics means that problem solving skills are the basic skills in learning mathematics".

Saidah argues (2014: 1), "The ability to solve mathematical problems is an effort in order to find solutions done by students when faced with problems that can be solved with skills, concepts, and mathematical processes". While Ruseffendi (Rahmawati, 2014: 4) says, "The problem in mathematics is a problem that can be solved by students without using routine methods or algorithms". NCTM (Wijayanti, 2012: 11) explains, "The ability of problem solving of mathematics is the ability or essential competence in learning mathematics, which is recommended to be trained and raised since child learn math from primary school until so on". That is, every student in every level of math ability and education level needs to be trained in problem-solving abilities. Mathematical problem solving can be interpreted as an attempt to identify the elements and solve non-routine math problems using routine methods.

The results of research conducted by Komariah (2011: 181) to the students of SMP Negeri in Kota Cimahi concluded, "The ability of students in solving the problem there has been no significant increase just an average increase of 3.7 from 52.4 to 56.1 ". The result of this research shows that students' mathematical problem solving ability is still lacking. Based on the study of beginners, Hasanah (2015) concluded that the problem solving ability of mathematics students of SMP Negeri in Cimahi City is still low. This is because the lack of understanding of the concepts to be studied and also students rarely get questions in the form of problem solving, thus making students confused in working on problem-solving problems.

According Kusmiati (2012: 9), "Problem-solving activities in the learning process of mathematics has not been used as the main activity. In fact, these activities can be said to be the core of school math learning activities ". Another factor that causes low students' mathematical problem solving abilities is the less effective approach and learning model, as Srimulyati (2014: 5) puts it.

Factors causing the lack of students' mathematical problem solving skills is a less precise learning process. The use of models, approaches and strategies in learning mathematics determine the ability to solve problems, activities, attitudes of students in learning, even the results achieved. Appropriate learning model will facilitate the implementation of learning and facilitate students in solving mathematical problems so as to achieve goals in accordance with the expected competencies.

Based on the above description comes the question of what models, approaches and learning strategies can train students' mathematical problem solving skills to be even better. There should be lessons that pay attention to how the condition or mood (mood) of students for learning that implemented can be more effective and optimal, so that students can train the ability to solve mathematical problems. The learning is a collaborative learning model of Mood, Understand, Recall, Digest, Expand and Review (MURDER) and a scientific approach in the Curriculum 2013. 
MURDER collaborative learning model is one of the lessons that pay attention to the mood that students have in the learning process. According Herdian (2010: 7), "Through learning MURDER students will be enthusiasm when learning because of a positive mood, students become more remember and improve understanding of the material". In addition disclosed by Fazrin (2010: 9), "MURDER is a collaborative learning technique that uses a pair of 2nd pair members from a group of 4 people in the learning process so that the purpose of learning can be achieved".

As for comparison, for other classes will be used scientific approach in Curriculum 2013. Implementation Curriculum 2013 in learning with scientific approach is a learning process designed in such a way that learners are active. According to Kemendikbud (Marlina, 2015: 4), "... the scientific approach is a means or mechanism to gain knowledge by procedures based on a scientific method ". Daryanto (Marlina, 2015: 4) argues, "Scientific-based learning is more effective than traditional learning". And affirmed by Hosnan (2014:37) in one of the learning objectives that use scientific or scientific approach is, "To establish the ability of students in solving a problem systematically".

Based on the above background, the researcher is interested in conducting research titled "Comparison of Mathematical Problem Solving Ability of Junior High School Students in Cimahi City between Using a Collaborative Learning Model of MURDER with Using a Scientific Approach".

\section{METHOD}

This research involves two groups, namely experimental group I and experiment group II. Both groups were given prets and postes. The experimental group I obtained the mathematics learning using the collaborative learning model of MURDER and the experimental group II obtained a mathematical learning with a scientific approach as treatment. In addition, the independent variables are manipulated. So according to the method, this research is an experimental study with a pretest posttest control group design that involves two groups and sampling is done by random class. Research design by Ruseffendi (2010: 50).
$\begin{array}{llll}\mathbf{A} & \mathrm{O} & \mathbf{X}_{1} & \mathrm{O}\end{array}$
$\begin{array}{llll}\mathbf{A} & \mathbf{O} & \mathbf{X}_{2} & \mathbf{O}\end{array}$
A : Random sampling by class
O : Pretik Problems = Problem Postes (Troubleshooting Troubleshooting Tests)
$\mathbf{X}_{\mathbf{1}} \quad$ : Treatment with collaborative learning MURDER
$\mathbf{X}_{2} \quad$ : Treatment with a scientific approach

Population in this research is all junior high school in Cimahi City which one of its characteristic have mean value of national exam of mathematics 54,8. Of all junior high schools in Cimahi, SMP Negeri 3 Cimahi was elected to have similar characteristics that have an average National Mathematics Exam score 54 for the academic year 2014/2015. From grade level that exist in SMP Negeri 3 Cimahi that class VII, VIII, and IX selected class VIII with consideration in second semester there is subject of linear equation of two variable which will be used in research. Sampling in this study randomly class, in random sampling technique each sampling unit as the element of the population get the same opportunity to be a sample or to represent the population, through the drawing conducted on 13 classes of class VIII SMP Negeri 3 Cimahi, then obtained class VIII -B (experimental class I) treated with collaborative learning model MURDER and class VIII-C (experimental class II) were given a study using a scientific approach. The data were processed through normality test, 
54 Effendi, A. S. H. Comparison Problem Solving Mathematics Students Junior High School in Cimahi City Between Using Murder Collaborative Learning Model with Using a Scientific Approach

homogeneity test, and two mean difference test, two-lane anova test and linear regression test using Minitab 17 software.

\section{RESULTS AND DISCUSSION}

\section{Results}

Below is a descriptive statistical data for mathematical problem solving abilities in both classes are as follows:

Table 1.

Recapitulation of Descriptive Statistics of Mathematical Problem Solving Ability

\begin{tabular}{lrrrr}
\hline \multirow{2}{*}{ Statistics } & \multicolumn{2}{c}{ Experiment Class I } & \multicolumn{2}{c}{ Experiment Class II } \\
\cline { 2 - 6 } & Pretest & Postest & Pretest & \multicolumn{1}{c}{ Postest } \\
\hline $\mathrm{N}$ & \multicolumn{5}{c}{38} \\
\hline $\mathrm{S}$ & 3,727 & 4,098 & 2,508 & 4,749 \\
\hline Max & 16 & 20 & 18 & 20 \\
\hline Min & 6 & 5 & 5 & 6 \\
\hline Average & 9,947 & 15,45 & 8,921 & 12,13 \\
\hline SMI & \multicolumn{5}{c}{20} \\
\hline
\end{tabular}

Based on Table 1, there is a difference between the experimental class I and the experimental class II. Where the average of experimental classes I and II has a difference of 1.027 and after obtaining the treatment the difference between the experimental class I and II increases by 3.34. Nevertheless from the data can not be drawn conclusions. For that researchers do statistical tests as follows:

Table 2.

Recapitulation of Pretest Data Pretest Results Ability Mathematical Problem Solving

\begin{tabular}{ccccc}
\hline Class & $\begin{array}{c}\text { Normality } \\
\text { Test }\end{array}$ & Interpretation & $\begin{array}{c}\text { Two Independent } \\
\text { Test }\end{array}$ & Interpretation \\
\cline { 1 - 3 } Experiment I & 0.010 & Abnormal & & there is no \\
Experiment II & 0.010 & Abnormal & 0.4238 & difference \\
\hline
\end{tabular}

Based on Table 2 it can be seen that the students in the experimental class I who used the collaborative learning model of MURDER and the experimental class II whose learning using the scientific approach had P-Value value $\leq 0.05$. Therefore experimental data of experimental class I and experiment class II are not normally distributed. Since the pretest results in experimental class I and experiment II class were not normally distributed, it was followed by non-paramentric tests using the Mann-Whitney test. Results of pretest data processing for experimental class I and experiment class II using Mann Whitney test has a significance value (P-Value) of 0.4238 which means $\mathrm{H} 0$ accepted. Thus there is no difference in the students' mathematical problem solving abilities among those using the collaborative learning model of MURDER with those using the scientific approach. 
Table 3.

Recapitulation of Postes Data Postest Capability Results Mathematical Problem Solving

\begin{tabular}{ccccc}
\hline Class & $\begin{array}{c}\text { Normality } \\
\text { Test }\end{array}$ & Interpretation & $\begin{array}{c}\text { Two Independent } \\
\text { Test }\end{array}$ & Interpretation \\
\hline Experiment I & 0.010 & Abnormal & \multirow{2}{*}{0.0025} & there is difference \\
\cline { 1 - 3 } Experiment II & 0.010 & Abnormal & & \\
\hline
\end{tabular}

Based on Table 3 it can be seen that the students in the experimental class I using the collaborative learning model of MURDER and the experimental class II whose learning using the scientific approach have significance value $<0.010$, then $\mathrm{P}-$ Value $\leq 0.05$. Then $\mathrm{H} 0$ is rejected which means the experimental class I post data and the experimental class II is not normally distributed. Since the postes data on the experimental class I and the experimental class II are not normally distributed, it is followed by a non-paramentric test using the MannWhitney test. The result of postes data processing for experimental class I and experiment class II using Mann Whitney test has a significance value (P-Value) of 0.0025 which means $\mathrm{HO}$ is rejected. Then there is the difference in students' mathematical problem solving abilities between using a collaborative learning model of MURDER with a scientific approach.

\section{Discussion}

Based on the results in the initial test data analysis, the average value of the two experimental classes has the same ability. Then when tested again using the Mann Whitney test to get similar results, ie there is no difference in the ability of the first problem solving of students' mathematical problems between the experimental class I and the second experimental class on the two-variable linear equations. The result of this pretest data shows that there is still a lack of students' mathematical problem solving abilities. This is because less students usually do problem solving problems, so there are still many students who find it difficult and confused when going to do the pretest problem.

The study was conducted ten times of meetings in both experimental classes, two meetings were held for pretest during initial meetings and postes at the last meeting and eight meetings were used for learning. Which experimental class I was treated using a collaborative learning model MURDER and experimental class II learning using scientific approach. After pretesting in both experiment classes, the next meeting is done by learning with two linear equation equation according to treatment.

Prior to the process of apersepsi, students are divided into several groups first. After the process of group formation, the teacher apersepsi on both classes regarding the matter of linear equations of two variables to recall the variables, coefficients and constants. Then after the apersepsi process, the teacher does the arrangement of atmosphere and the provision of stimulus followed by giving the student worksheet (LKS) to each group in the form of problem solving problems for experimental class I and the corresponding problem of characteristic of scientific approach for experiment class II.

In the experimental class I, learning is adapted to the steps that exist in the MURDER collaborative learning model. At the time of group division, students are given the freedom to 
56 Effendi, A. S. H. Comparison Problem Solving Mathematics Students Junior High School in Cimahi City Between Using Murder Collaborative Learning Model with Using a Scientific Approach

choose group mates. As the number of first-class experiment students is thirty-eight, it is divided into nine groups including seven groups consisting of four members and two groups of five members. Each group is subdivided into two pairs, namely dyad-1 and dyad-2 and followed by assigning assignments in the LKS to each pair. During the process of working on the problem in the LKS one member of the dyad-1 pair finds answers to the tasks for his partner and the other members writes while correcting if there is a mistake, also done by the dyad-2 spouse. After the pair dyad $\neg-1$ and dyad-2 couples finished doing their respective tasks, dyad-1 and dyad-2 paired each other to announce the answers they have found so that the problems in the LKS have been solved all. LKS were collected prepared according to collaborative groups, then the LKS were corrected, commented on, assessed, and discussed in class discussions.

While in experimental class II the learning using scientific approach adapted to the steps that is observing, asking, gathering information, associate and communicate the results of the discussion. Before the start of the learning process students are formed into six groups, because the number of students in the experimental class II is also thirty-eight so that the four groups of six students and two groups of seven students. Then each group is working on the LKS that has been given by the teacher. After all groups have finished working on LKS, there are at least two representative groups who present the results of the LKS worker and end by concluding the discussion with the teacher.

Obstacles experienced in the experimental class I using the MURDER collaborative learning model is not used to the students with the existing learning steps because new students first get the learning with this step. So that makes students a little confused and tend to focus more on the problems given to the dyad partner only. Then for the experimental class II that uses the scientific approach to the constraints that occur is when the process of communicating the results of group discussions. They only rely on students who will go forward to present the results, while others still do not quite understand when asked again about where the results were obtained. However, after several lessons in the experimental class I and the experimental class II, students become familiar with the lessons learned. So that the process of teaching and learning activities to be smooth without any constraints.

After the pretest and treatment done, the final test will be postes in both experimental classes. It aims to determine the students' mathematical problem solving abilities. The problem used in postes is the same problem at the time of pretest. Based on the results in the final test data analysis, the mean value in the experimental class I is greater than the experimental class II. Just looking at the average alone can already be seen that there is a difference of ability in both experiment classes. Then, when tested by Mann Whitney, it can be concluded that there is a difference of students' mathematical problem solving abilities between experimental class I using MURDER collaborative learning model with experimental class II with learning using scientific approach. This research is successful because it is supported by several factors including:

1. Research in accordance with the procedures and learning steps.

2. Processing all data in accordance with the accuracy of its analysis.

\section{CONCLUSION}

Based on the data analysis and discussion described in the previous chapter, the researcher concludes that there are differences in students' mathematical problem solving abilities that use the MURDER Collaborative learning model with the learning using scientific approach. 


\section{REFERENCES}

Fazrin, N. (2010). Penerapan Teknik MURDER dalam Pengajaran Pembelajaran Berdiskusi pada Siswa SMK PGRI 2 Cimahi [Online]. Tersedia: http://www.repository.upi.edu. (Diakses 8 Juli 2015)..

Hasanah, L. N. (2016). Perbandingan Kemampuan Pemecahan Masalah Matematis Siswa SMP Negeri di Kota Cimahi antara yang Menggunakan Model Pembelajaran Kolaboratif MURDER dengan yang Menggunakan Pendekatan Saintifik [Studi Pemula]. Cimahi: Tidak diterbitkan.

Herdian (2010). Model Pembelajaran Kolaboratif MURDER [Online]. Tesedia: http://herdy07.wordpress.com/2010/05/27/model-pembelajaran-kolboratif-MURDER. (Diakses 8 Juli 2015).

Hosnan, M. (2014). Pendekatan Saintifik dan Kontekstual dalam Pembelajaran Abad 21. Bogor: Ghalia Indoensia.

Juanda, R. Y. (2013). Penerapan Model Pembelajaran Kooperatif Tipe Mood-UnderstandRecall-Digest-Expand-Review untuk Meningkatkan Kemampuan Berpikir Kritis dan Pemecahan Masalah Matematis Siswa SMP. Tesis UPI. Bandung: Tidak diterbitkan.

Komariah, K. (2011). Penerapan Metode Pembelajaran Problem Solving Model Polya untuk Meningkatkan Kemampuan Pemecahan Masalah bagi Siswa Kelas IX-J di SMPN 3 Cimahi [Online]. Tersedia: http://www.core.ac.uk/download/pdf/11064766.pdf. (Diakses 5 Juli 2015).

Kusmiati, E. (2012). Pengaruh Pendekatan Open Ended terhadap Peningkatan Kemampuan Pemecahan Masalah Matematika Siswa Sekolah Dasar. Skripsi STKIP Siliwangi. Cimahi: Tidak diterbitkan.

Marlina, M. (2015). Perbandingan Kemampuan Penalaran Matematik Siswa SMP Negeri di Kota Cimahi antara yang Pembelajarannya Menggunakan Pendekatan Problem Solving dengan Pendekatan Saintifik. Skripsi STKIP Siliwangi. Cimahi: Tidak Diterbitkan.

Rahmawati, I. (2014). Pengaruh Pembelajaran Inkuiri Model Silver terhadap Peningkatan Kemampuan Representasi dan Pemecahan Masalah Matematis Siswa SMP [Online]. Tersedia: http://repository.upi.edu. (Diakses 8 Juli 2015).

Ruseffendi, E. T. (2006). Pengantar kepada Membantu Guru Mengembangkan Kompetensinya dalam Pengajaran Matematika untuk Meningkatkan CBSA. Bandung: Tarsito.

Saidah, N. (2014). Peningkatan Kemampuan Pemecahan Masalah Matematika Materi Pecahan melalui Pendekatan Pendidikan Matematika Realistik Indonesia pada Siswa Kelas IV SD 2 Gribid Tahun Pelajaran 2013/2014 [Online]. Tersedia: http://eprint.umk.ac.id/3175/1/1.-bagian-awal.pdf. (Diakses 8 Juli 2015). 
58 Effendi, A. S. H. Comparison Problem Solving Mathematics Students Junior High School in Cimahi City Between Using Murder Collaborative Learning Model with Using a Scientific Approach

Srimulyati, S. (2014). Penerapan Pendekatan Open-Ended terhadap Peningkatan Kemampuan Pemecahan Masalah Matematis Siswa MTs. Skripsi STKIP Siliwangi. Cimahi: Tidak diterbitkan.

Wijayanti, A. (2012). Penerapan Model Connecting, Organizing, Reflecting, Extending (CORE) untuk Meningkatkan Kemampuan Pemecahan Masalah Matematis Siwa SMP Bandung [Online]. Tersedia: http://wijayantianisa.blogspot.com/2012/07/penerapanmodel-connecting-organizing.html\#. ( Diakses 25 juni 1015). 